\title{
Review Paper on Application of Waste Plastic in Modifying Bitumen Properties
}

\author{
AdityaBhardwaj ${ }^{a}$ Bal Krishna Keshav ${ }^{b}$, AkulDev Singh ${ }^{c}$ \\ a. B.Tech Student, Civil Engineering department, Graphic Era University, Dehradun \\ (Email id: harsh23bhardwaj.23@gmail.com) \\ b. B.Tech Student, Civil engineering department, Graphic Era University, Dehradun \\ (Email id: balkrishankeshav@gmail.com) \\ c. B.Tech Student, Civil Engineering department, Graphic Era University, Dehradun \\ (Email id: akulsingh53@gmail.com)
}

\begin{abstract}
Industrialisation and population is increasing day by day leading to the increase in the amount of waste plastic. Plastic is a non-biodegradable substance i.e. it is not decomposed by bacteria easily. So, dumping it causes soil pollution which leads to decrease in the fertility of soil. Another way of getting rid of plastic is by burning it, which also produces a lot of harmful gases and leads to increase in air pollution. Soil and air pollution both are harmful for the environment. Waste plastic can be used in bitumen as a modifier. In this paper we will discuss the variation of the properties of bitumen on addition of waste plastic at different percentage.
\end{abstract}

Keywords: Non biodegradable, Pollution, Environment

\section{INTORDUCTION}

Plastic is a substance which has a broad range of synthetic or semi synthetic organic compounds which are malleable and can be casted into different types of solid objects. It is user friendly and durable but not eco-friendly and also they are non-biodegradable. The chemical bond which makes it durable tends to make it resistant to the different natural process of degradation. 'Bakelite' the first fully synthetic plastic was discovered in 1997 in New York by Leo Baekeland who gave the term plastic.

Due to its low cost, easy manufacturing and impervious to water, plastics are used in an excessive and manufacturing wide range of products. India has become the third largest consumer of plastic in the world with the consumption of around 15 million used for packing material which are often thrown and left to litter the surroundings. They also have a characteristic of a very long life and burning of these waste plastic under uncontrolled conditions could also lead to generation of much hazardous air pollutants depending upon the type of polymers.

The littered plastic which is nonbiodegradable gets mixed with the domestic waste and creates difficulty in disposal of municipal waste. There are two methods of municipal waste disposal, land filled or incinerated. Both dumping methods are not suitable for plastic and hence cause soil and air pollution. With the Industrialisation and huge increment in population growth there is the increase in different types of plastic waste products. Waste plastics i.e. polythenes, carry bags, etc. softens on heating on around $130^{\circ} \mathrm{C}$, in the temperature range of 130 $180^{\circ} \mathrm{C}$, and softened plastic have a binding property, hence the molten plastic can be used as binder or mixed with the bitumen to enhance its properties. This could be great enhancer of bitumen used in road construction.

\section{BITUMEN}

Indian Standard Institutions defines bitumen as a black or dark brown non crystalline soil or viscous material having adhesive properties derived from petroleum crude either by natural or by refinery processes. In other words bitumen is any adhesive and solid mixture of hydrocarbons that are found naturally in tar, asphalt, mineral waxes, etc. used for constructing the road surface and roofing material. It is mainly used for:

- Construction of roads, platforms, runways etc

- Water proofing

- Mastic flooring

- Canal lining

- Damp proof course

Advantage of bitumen:

- Production of bitumen is economical

- Rheological and physical properties of bitumen bring versatility

- Favourable melting point

- Bitumen can go under recycling

- Adhesive in nature 
It is estimated that 102 million tonnes bitumen is used by the world and around $85 \%$ of the bitumen produced are used as a binder in road construction. It is also used in other pavements such as airport runways, car parking's, footways etc.

Road surface with cluttered bitumen may cause bleeding in hot weather and may develop cracks in cold weather possess fewer loads bearing capacity and can cause serious damages because of higher axial load in present conditions due to rapid infrastructure development. In the both terms length and quality, India has to raise its transportation system. Generally, production of asphalt comprises blending crushed rocks, fine aggregate with bitumen, which acts as a binding agent. Materials such as polymers could be added to alter its chemical and physical properties according to the use for which the asphalt is basically destined. Around the world, road authorities are realizing the use of modified bitumen is profitable in the road construction. Polymer modified bitumen is developed as one of the best construction material used for the flexible pavement. It reduces medium and long term cost as the roads are less exposed to defects. This reduces maintenance cost, which is not only a financial problem but also a traffic problem as road has to be closed for repairing or maintenance. Using waste plastic as enhancer in bituminous mix not only modify the properties of mix but also solve the problem of disposal of plastic and also creates employment to plastic collector.

\section{LITERATURE REVIEW}

Athira R Prasad etal (2015) Says that the bitumen which is conventional material used in the road construction can be partially replaced by the waste plastic and rubber. They added rubber and PET in $3 \%, 4.5 \%, 6 \%, 7.5 \%$ and $8 \%$ in bitumen and found that the optimum content was obtained at $6 \%$. Thus according to their study the use of plastic in $6 \%$ by weight of bitumen improves the pavement stability. And they found the use of PET bottle is best. Therefore the disposal of rubber and PET is best in the road construction.

Anurag V. Tiwarietal (2015) As plastics has non-biodegradable characteristics and Are also harmful to human health therefore disposal of waste plastic is of great concern to the environmental engineers. The roads in India are mostly flexible type and made of bituminous concrete. As bitumen is been extracted from naturally occurring crude oil therefore has its limitation on the availability therefore there is the need of an alternative material. Their papers compose of literature and processes for use of waste plastic in the construction of roads. And also aims to reduce the environmental pollution created by plastic in economic way by using the plastic waste in the construction of road.

Bright Aforlaetal (2015) According to them by adding waste plastic the property of bitumen has increased. With two per cent of polymer composition with AC-10 bitumen can give AVC-20bitumen properties which will finally help in improving the marshal stability design life strength and other desirable property. The asphalt pavement shows saving in usage of bitumen as consumption of waste plastic increases. The disposal of waste plastic in the bituminous pavement construction is therefore a permanent solution and hence which establish the safe and healthy environment.

Mahesh M Barad (2015) Explains that modified bitumen by polymer shows good properties as compare to normal bitumen. But if we add more per cent of plastic in bitumen the blend gets separates on cooling. And which finally affect the properties of bitumen. In the dry process the aggregate are coated with plastic. The aggregate coated with plastic shows the improved binding properties as due to increased area of contact between bitumen and polymer.

S.Rajasekaranetal (2013) Explains that by coating the aggregate with the polymer has many advantages and which ultimately helps in improving the flexible pavement quality not only it improve the pavement quality but also improve the aggregate quality. This technology also helps in the disposal of waste plastic obtained from the domestic and industrial packing materials. The dry process is more valuable as it dispose the $80 \%$ of waste polymer in eco-friendly way. And use of polymer reduces the equivalent bitumen quantity and therefore reducing the construction cost of road.

Sasane Neha .B etal (2015) Explains that the addition of plastic is the innovative technology which strengthen the road construction and also increases the life of road. As the plastic content increase the property of bitumen and aggregate also increases compared to conventional flexible pavement the flexible pavement with the added plastic has good results. According to marshal stability test the optimum use of plastic is up to $10 \%$.

\section{CONCLUSION}

From the study of various research papers we can conclude that,

1. By adding waste plastic to the bitumen the properties of bitumen has been optimized.

2. Not only waste plastic improved the properties of bitumen but also improve the properties of bituminous mix. 
3. Thus, the use of waste plastic ultimately improves the performance and quality of flexible pavement.

4. As plastic are non-biodegradable and also harmful to environment thus, disposal of plastic is a matter of great concern therefore use of waste plastic in the road construction is an effective way of disposal of waste plastic.

\section{REFERENCES}

[1]. Anurag V. Tiwariet. al. Plastic Waste Modified Bitumen for Road Construction Journal of Engineering Research and Studies JERS Volume 2015-16, 2 July 2015.

[2]. Athira R Prasad Bituminous Modification with Waste Plastic and Crumb Rubber IOSR Journal of Mechanical and Civil Engineering (IOSR-JMCE) Volume 12, Issue 3 Ver. II (May - Jun. 2015).

[3]. Bright Aforla Assessment of Suitability of Plastic Waste in Bituminous Pavement Construction Civil and Environmental Research Vol.7, No.11, 2015.

[4]. Mahesh M BaraduseOf Plastic In Bituminous Road Construction Journal Of Information, Knowledge And Research In Civil Engineering Volume 3, Issue 2 November 14 to October 15.

[5]. SasaneNeha. B Application Of Waste Plastic As An Effective Construction Material In Flexible Pavement International Research Journal of Engineering and Technology (IRJET) Volume: 02 Issue: 03, June-2015.

[6]. S.Rajasekaranet. al. Reuse of Waste Plastics Coated Aggregates-Bitumen Mix Composite For Road Application - Green Method American Journal of Engineering Research (AJER) Volume-02, Issue-11, 2013. 